\title{
Effect of Dietary Vitamin E on Growth Performance, Immunity and Antioxidant Capacity in Male Jiangnan White Goslings from 1 to $28 \mathrm{~d}$ of Age
}

\author{
Qingyu Sun ${ }^{1}$, Haiming Yang ${ }^{1, *}$, Jun $\mathrm{Yu}^{1}{ }^{1}$, Jingru Liang ${ }^{1}$, Xuean $\mathrm{Xu}^{1}$ and Zhiyue Wang ${ }^{1,2} \mathbb{D}$ \\ 1 College of Animal Science and Technology, Yangzhou University, No. 48 Wenhui East Road, \\ Yangzhou 225009, China; sqy203610@163.com (Q.S.); DX120190125@yzu.edu.cn (J.Y.); \\ Liangliangjingru2022@163.com (J.L.); xuxuean1996@163.com (X.X.); zywang@yzu.edu.cn (Z.W.) \\ 2 Joint International Research Laboratory of Agriculture and Agri-Product Safety of Ministry of Education of \\ China, Yangzhou University, Yangzhou 225009, China \\ * Correspondence: hmyang@yzu.edu.cn; Tel.: +86-514-87979045; Fax: +86-514-87990256
}

\section{check for} updates

Citation: Sun, Q.; Yang, H.; Yu, J.; Liang, J.; Xu, X.; Wang, Z. Effect of Dietary Vitamin E on Growth Performance, Immunity and Antioxidant Capacity in Male Jiangnan White Goslings from 1 to 28 d of Age. Agriculture 2022, 12, 83. https://doi.org/10.3390/

agriculture12010083

Academic Editor: Maria

Grazia Cappai

Received: 10 December 2021

Accepted: 5 January 2022

Published: 10 January 2022

Publisher's Note: MDPI stays neutral with regard to jurisdictional claims in published maps and institutional affiliations.

Copyright: (C) 2022 by the authors. Licensee MDPI, Basel, Switzerland. This article is an open access article distributed under the terms and conditions of the Creative Commons Attribution (CC BY) license (https:// creativecommons.org/licenses/by/ $4.0 /)$.

\begin{abstract}
This experiment aimed to investigate effects of the different dietary levels of vitamin E (VE) on the growth performance, immunity and antioxidant capacity of goslings. A total of 2401 -day-old, male Jiangnan white goslings were selected and randomly divided into 6 groups. Each treatment included five replicates. The basal diet was supplemented with 6 concentrations of VE $(0,12,24$, 36,48 and $60 \mathrm{mg}$ DL- $\alpha$-tocopherol acetate $/ \mathrm{kg}$ ). The results were as follows: (1) The $\alpha$-tocopherol content in the serum and liver of goslings increased linearly as supplemental VE increased in diet $(p<0.05)$. (2) The body weight (BW) and average daily gain (ADG) increased quadratically with increasing dietary VE supplementation $(p<0.05)$. Dietary VE supplementation could significantly reduce the feed/gain ratio $(\mathrm{F} / \mathrm{G})(p<0.05)$. (3) Dietary supplementation with VE could significantly improve the contents of immunoglobulin A ( $\operatorname{IgA})$ and immunoglobulin $\mathrm{G}(\operatorname{IgG})$ in the serum of the goslings $(p<0.05)$. The content of interferon- $\gamma($ IFN- $\gamma)$ in the serum was significantly reduced with VE supplementation $(p<0.05)$. (4) Dietary supplementation with VE could significantly improve serum and liver catalase (CAT), superoxide dismutase (SOD) activities and liver total antioxidant capacity (T-AOC) $(p<0.05)$; Serum and liver MDA contents were significantly reduced with VE supplementation $(p<0.05)$. In summary, dietary supplementation with VE could improve growth performance, immunity and antioxidant capacity. Based on broken-line regression analysis, the dietary VE supplementation level for ADG was $12.51 \mathrm{mg} / \mathrm{kg}$, but higher supplementation level should be considered to improve immunity and antioxidant capacity.
\end{abstract}

Keywords: gosling; vitamin E; growth performance; immunity; antioxidant capacity

\section{Introduction}

Vitamin E (VE), divided into tocopherols and tocotrienols, is one of the essential fatsoluble vitamins for animals. Animals that cannot synthesize VE must obtain it from the diet [1]. $\alpha$-Tocopherol has high biological activity and is the main storage form of VE in animal tissues accounting for more than $90 \%$ of VE [2]. The content of $\alpha$-tocopherol in the blood and liver were shown to depend on the dietary VE levels added to feed [3].

VE could improve immunity and antioxidant capacity [4] and was shown to play a very important role in poultry production. The average daily gain (ADG) of broilers in the $100 \mathrm{mg} / \mathrm{kg}$ VE group was significantly higher than that in the control group supplemented with $18.75 \mathrm{mg} / \mathrm{kg} \mathrm{VE} \mathrm{[5].} \mathrm{Chae} \mathrm{et} \mathrm{al.} \mathrm{[6]} \mathrm{reported} \mathrm{that} \mathrm{adding} \mathrm{10-200} \mathrm{mg/kg} \alpha$-tocopherol acetate to broiler diets could significantly improve growth performance compared with that of the control group with no supplementation. Adding 5-100 mg/kg $\alpha$-tocopherol acetate to starter White Pekin duck diet was shown to significantly improve growth performance compared with that of the control group with no supplementation [7]. VE is an important 
regulatory factor in the immune response that can enhance humoral and cellular immune responses. The levels of interferon- $\gamma$ (IFN- $\gamma$ ) in the plasma and tissues of broiler chicks were shown to be lower in the $50 \mathrm{mg} / \mathrm{kg} R R R$ - $\alpha$-tocopherol succinate group than that in the $10 \mathrm{mg} / \mathrm{kg}$ RRR- $\alpha$-tocopherol succinate group [8]. Adding $220 \mathrm{mg} / \mathrm{kg} \alpha$-tocopherol acetate to broiler diets was shown to relieve inflammation [9]. As the main antioxidant of the cell membrane, VE is a chain-breaking antioxidant, that can prevent the formation of free radicals in cell membrane [10,11]. When animals lack VE, the content of $\alpha$-tocopherol in tissues decreases and the degree of lipid peroxidation increases [12].

At present, some studies have shown that appropriate VE supplementation in diet can improve the growth performance, immunity, and antioxidant capacity of poultry. Although there were studies on VE in goslings [13,14], there have been few studies to determine appropriate VE supplementation in the diet of goslings. Therefore, the objective of this study was to investigate the effects of different supplemental doses of VE on growth performance, immunity and antioxidant capacity as a reference for the production of goslings.

\section{Materials and Methods}

\subsection{Experimental Design and Diets}

The Yangzhou University (Yangzhou, China) Animal Care and Use Committee approved all procedures in our experiments, with permit number: SYXK (Su) IACUC 20120029.

A total of 240 1-day-old, male Jiangnan white goslings were selected and randomly divided into 6 experimental groups. Each treatment included five replicates. The basal diet was supplemented with 6 concentrations of VE $(0,12,24,36,48$ and $60 \mathrm{mg} / \mathrm{kg})$. The form of VE added to the feed was DL- $\alpha$-tocopherol acetate. DL- $\alpha$-tocopherol acetate was purchased from Yangzhou Shuangyang Biological Co., Ltd. (Yangzhou, China). A basal maize-soybean meal diet was formulated to provide an adequate concentration of all the nutrients, except for VE, required by goslings NRC [15] and optimized in our laboratory over the years (Table 1). All goslings had free access to feed and water. The goslings were maintained under natural daylight and ventilation and kept at a temperature of $28 \pm 3{ }^{\circ} \mathrm{C}$. The size of each pen was $2.52 \mathrm{~m}^{2}(2.10 \mathrm{~m} \times 1.20 \mathrm{~m})$.

\subsection{Sample Collection and Index Determination \\ 2.2.1. $\alpha$-Tocopherol Content}

The content of $\alpha$-tocopherol in feed, serum and liver was determined using reversed phase high performance liquid chromatography (2695 Alliance, Waters, Milford, MA, USA) with fluorescence detection according to the method of Jensen et al. [16].

\subsubsection{Growth Performance}

On day 28, goslings were weighed after a 6-h fast and feed intake was recorded in replicates to calculate average daily gain (ADG) and average daily feed intake (ADFI). The feed/gain ratio (F/G) was calculated as the ratio between the ADFI and ADG of each replicate. The body weight (BW) and feed intake were recorded by an electronic platform scale (acs-30 Shanghai Yousheng Co., Ltd., Shanghai, China).

\subsubsection{Immunity}

The contents of serum immunoglobulin $\mathrm{M}(\operatorname{IgM})$, immunoglobulin A (IgA), immunoglobulin G (IgG), interleukin-6 (IL-6) and interferon- $\gamma$ (IFN- $\gamma$ ) were measured by double antibody sandwich enzyme-linked immunosorbent assay (ELISA) using commercial kits from Shanghai Yubo Biology Co., Ltd. (Shanghai, China). 
Table 1. Composition and nutrient level of the basic gosling diet (dry basis).

\begin{tabular}{|c|c|}
\hline Item & Content \\
\hline \multicolumn{2}{|l|}{ Ingredients (\%) } \\
\hline Corn & 59.50 \\
\hline Soybean meal & 31.10 \\
\hline Rice husk & 2.90 \\
\hline Wheat bran & 2.96 \\
\hline Methionine & 0.14 \\
\hline Salt & 0.30 \\
\hline Stone powder & 0.75 \\
\hline Calcium hydrogen phosphate & 1.25 \\
\hline Choline chloride & 0.10 \\
\hline Premix ${ }^{1}$ & 1.00 \\
\hline Total & 100.00 \\
\hline \multicolumn{2}{|l|}{ Nutritional level $^{2}$} \\
\hline $\mathrm{ME}(\mathrm{MJ} / \mathrm{kg})$ & 11.40 \\
\hline Crude protein (\%) & 19.30 \\
\hline Crude fiber $(\%)$ & 4.89 \\
\hline $\mathrm{Ca}(\%)$ & 0.80 \\
\hline Available phosphorus (\%) & 0.42 \\
\hline Lysine $(\%)$ & 0.97 \\
\hline Methionine $(\%)$ & 0.42 \\
\hline$\alpha$-tocopherol $(\mathrm{mg} / \mathrm{kg})^{2}$ & 15.45 \\
\hline
\end{tabular}

\subsubsection{Antioxidant Capacity}

Each liver sample was accurately weighed to $0.5 \mathrm{~g}$, and a 9-fold volume of physiological saline by weight was added. The sample was homogenized under ice bath conditions by a variety of fast homogenizers. By using a DL-5 M low-speed refrigerated centrifuge at $2500 \mathrm{r} / \mathrm{min}$, the liver samples were centrifuged for $10 \mathrm{~min}$, one portion was retained for inspection, and the others were stored at $-70{ }^{\circ} \mathrm{C}$ for later testing. The DL5 M low-speed refrigerated centrifuge was purchased from Hunan Xiangyi Centrifuge Instrument Co., Ltd., (Hunan, China). The catalase (CAT), glutathione peroxidase (GSH-Px) and superoxide dismutase (SOD) activities; total antioxidant capacity (T-AOC); and malondialdehyde (MDA) content in serum and liver were determined by using an assay kit purchased from Nanjing Jiancheng Bioengineering Research Institute (Nanjing, China) and following the operation manual.

\subsection{Statistical Analysis}

Data were analyzed using SPSS 17.0 (SPSS, 2009) by univariate variance analysis (ANOVA) following Tukey test to elucidate significant differences at $p<0.05$. VE supplementation level was estimated from the ADG using broken-line regression model analysis [17]. If the value of $R^{2}$ was less than 0.50 , we would not use broken-line regression model to analyze the data.

\section{Results}

\subsection{Serum and Liver $\alpha$-Tocopherol Content}

The content of $\alpha$-tocopherol in the liver and serum increased linearly with increasing dietary VE supplementation $(p<0.05)$ (Table 2$)$. 
Table 2. Effect of dietary vitamin E supplementation on $\alpha$-tocopherol content in the serum and liver of male Jiangnan white goslings on day 28.

\begin{tabular}{|c|c|c|c|c|c|c|c|c|c|c|}
\hline \multirow{2}{*}{ Item } & \multicolumn{6}{|c|}{ Vitamin E Supplementation Level (mg/kg) } & \multirow{2}{*}{ SEM } & \multicolumn{3}{|c|}{$p$-Value } \\
\hline & $0^{1}$ & 12 & 24 & 36 & 48 & 60 & & Vitamin E & Linear & Quadratic \\
\hline Serum (ug/mL) & $1.20^{\mathrm{d}}$ & $2.76^{\mathrm{c}}$ & $3.87^{b, c}$ & $4.65^{\mathrm{b}}$ & $6.93^{\mathrm{a}}$ & $7.96^{\mathrm{a}}$ & 0.44 & $<0.001$ & $<0.001$ & 0.338 \\
\hline Liver (ug/g) & $1.43^{\mathrm{d}}$ & $1.91^{\mathrm{d}}$ & $3.07^{\mathrm{c}}$ & $3.55^{b, c}$ & $3.99^{b}$ & $4.59^{\mathrm{a}}$ & 0.21 & 0.001 & $<0.001$ & 0.075 \\
\hline
\end{tabular}

\subsection{Growth Performance}

The effect of dietary VE supplementation on the growth performance of goslings on day 28 is shown in Table 3. The BW and ADG of gosling in groups with 12, 36, 48 and $60 \mathrm{mg} / \mathrm{kg}$ supplementation were higher than those of the group with $0 \mathrm{mg} / \mathrm{kg}$ supplementation $(p<0.05)$. Dietary VE supplementation had no significant effects on ADFI ( $p>0.05)$. The F/G of goslings in groups with 36 and $48 \mathrm{mg} / \mathrm{kg}$ supplementation was less than that of the group with $0 \mathrm{mg} / \mathrm{kg}$ supplementation $(p<0.05)$. The optimal VE supplementation level for male Jiangnan white goslings from 1 to $28 \mathrm{~d}$ of age was $12.51 \mathrm{mg} / \mathrm{kg}$ for maximum ADG (Table 4).

Table 3. Effect of dietary vitamin E supplementation on the growth performance of male Jiangnan white goslings from hatching to $28 \mathrm{~d}$.

\begin{tabular}{|c|c|c|c|c|c|c|c|c|c|c|}
\hline \multirow{2}{*}{ Item $^{1}$} & \multicolumn{6}{|c|}{ Vitamin E Supplementation Level (mg/kg) } & \multirow{2}{*}{ SEM } & \multicolumn{3}{|c|}{$p$-Value } \\
\hline & $0^{2}$ & 12 & 24 & 36 & 48 & 60 & & Vitamin E & Linear & Quadratic \\
\hline Hatch weight (g) & 94.3 & 94.8 & 94.4 & 94.3 & 94.6 & 94.5 & 0.09 & 0.519 & 0.688 & 0.950 \\
\hline $28 \mathrm{~d} \mathrm{BW}(\mathrm{g})$ & $1586.8^{b}$ & $1679.0^{\mathrm{a}}$ & $1659.2^{a, b}$ & $1716.4^{\mathrm{a}}$ & $1676.2^{\mathrm{a}}$ & $1684.0^{\mathrm{a}}$ & 10.67 & 0.005 & 0.005 & 0.013 \\
\hline ADG $(g)$ & $53.3^{\mathrm{b}}$ & $56.6^{\mathrm{a}}$ & $55.9^{\mathrm{a}, \mathrm{b}}$ & $57.9^{a}$ & $56.5^{\mathrm{a}}$ & $56.8^{\mathrm{a}}$ & 0.38 & 0.005 & 0.005 & 0.013 \\
\hline ADFI (g) & 116.8 & 119.3 & 117.1 & 119.0 & 116.9 & 118.9 & 0.70 & 0.831 & 0.748 & 0.903 \\
\hline $\mathrm{F} / \mathrm{G}(\mathrm{g} / \mathrm{g})$ & $2.19^{\mathrm{a}}$ & $2.11^{\mathrm{a}, \mathrm{b}}$ & $2.10^{a, b}$ & $2.06^{b}$ & $2.07^{b}$ & $2.10^{a, b}$ & 0.01 & 0.014 & 0.005 & 0.010 \\
\hline
\end{tabular}

${ }^{1} \mathrm{BW}=$ body weight; ADG = average daily gain; ADFI = average daily feed intake; $\mathrm{F} / \mathrm{G}=$ The feed/gain ratio ${ }^{2}$ The content of $\alpha$-tocopherol in the basal diet was $15.45 \mathrm{mg} / \mathrm{kg}$; ${ }^{\mathrm{a}, \mathrm{b}}$ Means with different superscripts within the same column differ significantly $(p<0.05)$.

Table 4. Vitamin E supplementations of male Jiangnan white goslings from 1 to $28 \mathrm{~d}$ of age based on broken-line regression analysis.

\begin{tabular}{ccccc}
\hline Response Criterion $^{1}$ & Regression & Supplementation $(\mathbf{m g} / \mathbf{k g})$ & $\boldsymbol{p}$-Value & $\boldsymbol{R}^{\mathbf{2}}$ \\
\hline ADG & $\mathrm{Y}=57.2175-0.3544(12.51-\mathrm{x})$ & 12.51 & 0.0002 & 0.56 \\
Serum INF- $\gamma$ content & $\mathrm{Y}=41.1400+0.4100(38.12-\mathrm{x})$ & 38.12 & $<0.0001$ & 0.61 \\
Liver MDA content & $\mathrm{Y}=0.4601+0.0072(25.94-\mathrm{x})$ & 25.94 & $<0.0001$ & 0.50 \\
\hline
\end{tabular}

${ }^{1}$ ADG = average daily gain; IFN- $\gamma=$ interferon $-\gamma$; MDA = malondialdehyde.

\subsection{Immunity}

The effect of dietary VE supplementation on the immunity of goslings on day 28 is presented in Table 5. The content of IgA in the serum of goslings in the 36 and $48 \mathrm{mg} / \mathrm{kg}$ groups was higher than that in the $0 \mathrm{mg} / \mathrm{kg}$ group $(p<0.05)$. The content of $\mathrm{IgM}$ in the serum of goslings in all groups had no differences $(p>0.05)$. The IgG content in the serum of the goslings in the $48 \mathrm{mg} / \mathrm{kg}$ group was higher than that in the $0 \mathrm{mg} / \mathrm{kg}$ group $(p<0.05)$. Dietary VE supplementation showed no significant effects on the content of IL-6 in serum $(p>0.05)$. The content of IFN- $\gamma$ in serum $48 \mathrm{mg} / \mathrm{kg}$ was less than that of $0 \mathrm{mg} / \mathrm{kg}$ group $(p<0.05)$. Table 4 shows that the VE supplementation for male Jiangnan white goslings from 1 to 28 days of age was $38.121 \mathrm{mg} / \mathrm{kg}$ of the diet for minimum content of IFN- $\gamma$. 
Table 5. Effect of dietary dietary vitamin E supplementation on immunity in the serum of male Jiangnan white goslings on day 28.

\begin{tabular}{|c|c|c|c|c|c|c|c|c|c|c|}
\hline \multirow{2}{*}{ Item $^{1}$} & \multicolumn{6}{|c|}{ Vitamin E Supplementation Level (mg/kg) } & \multirow{2}{*}{ SEM } & \multicolumn{3}{|c|}{$p$-Value } \\
\hline & $0^{2}$ & 12 & 24 & 36 & 48 & 60 & & Vitamin E & Linear & Quadratic \\
\hline $\operatorname{Ig} \mathrm{A}(\mathrm{mg} / \mathrm{mL})$ & $0.14^{\mathrm{b}}$ & $0.16^{a, b}$ & $0.16^{a, b}$ & $0.22^{\mathrm{a}}$ & $0.22^{\mathrm{a}}$ & $0.19^{a, b}$ & 0.01 & 0.005 & 0.002 & 0.066 \\
\hline $\operatorname{IgM}(\mathrm{mg} / \mathrm{mL})$ & 1.81 & 1.82 & 1.96 & 2.18 & 2.07 & 1.95 & 0.04 & 0.069 & 0.039 & 0.067 \\
\hline $\operatorname{IgG}(\mathrm{mg} / \mathrm{mL})$ & $1.63^{\mathrm{b}}$ & $1.70^{\mathrm{a}, \mathrm{b}}$ & $1.70^{\mathrm{a}, \mathrm{b}}$ & $1.87^{\mathrm{a}, \mathrm{b}}$ & $2.09^{\mathrm{a}}$ & $1.82^{a, b}$ & 0.05 & 0.028 & 0.008 & 0.349 \\
\hline IL-6 (ng/L) & 24.81 & 24.34 & 21.16 & 21.42 & 21.85 & 23.08 & 0.70 & 0.574 & 0.290 & 0.167 \\
\hline IFN- $\gamma(\mathrm{ng} / \mathrm{L})$ & $57.79^{a}$ & $51.52 \mathrm{a}, \mathrm{b}$ & $45.34^{a, b}$ & $43.27^{a, b}$ & $39.23^{b}$ & $43.04^{a, b}$ & 1.43 & $<0.001$ & $<0.001$ & $<0.001$ \\
\hline
\end{tabular}

${ }^{1}$ IgM = immunoglobulin M; IgA = immunoglobulin A; IgG = immunoglobulin G; IL-6 = Interleukin-6; IFN- $\gamma=$ interferon $-\gamma ;{ }^{2}$ The content of $\alpha$-tocopherol in the basal diet was $15.45 \mathrm{mg} / \mathrm{kg} ;{ }^{\mathrm{a}, \mathrm{b}}$ Means with different superscripts within the same column differ significantly $(p<0.05)$.

\subsection{Antioxidant Capacity}

Table 6 shows that the effect of dietary VE supplementation on the serum antioxidant capacity of goslings on day 28 . The serum CAT activity of goslings in groups with 24,36 and $48 \mathrm{mg} / \mathrm{kg}$ supplementation was higher than that of group $0 \mathrm{mg} / \mathrm{kg}(p<0.05)$. Dietary VE supplementation had no effects on GSH-Px activity and T-AOC $(p>0.05)$. The SOD activity of goslings in group with $36 \mathrm{mg} / \mathrm{kg}$ supplementation was higher than that of group $0 \mathrm{mg} / \mathrm{kg}(p<0.05)$. The serum MDA content in groups $24,36,48$ and $60 \mathrm{mg} / \mathrm{kg}$ significant less than that of group $0 \mathrm{mg} / \mathrm{kg}(p<0.05)$.

Table 6. Effect of dietary vitamin E supplementation on the antioxidant capacity in the serum of male Jiangnan white goslings on day 28.

\begin{tabular}{|c|c|c|c|c|c|c|c|c|c|c|}
\hline \multirow{2}{*}{ Item $^{1}$} & \multicolumn{6}{|c|}{ Vitamin E Supplementation Level (mg/kg) } & \multirow{2}{*}{ SEM } & \multicolumn{3}{|c|}{$p$-Value } \\
\hline & $0^{2}$ & 12 & 24 & 36 & 48 & 60 & & Vitamin E & Linear & Quadratic \\
\hline CAT (U/mL) & $2.44^{\mathrm{b}}$ & $2.80^{\mathrm{a}, \mathrm{b}}$ & $2.97^{\mathrm{a}}$ & $2.92^{\mathrm{a}}$ & $2.87^{\mathrm{a}}$ & $2.82^{a, b}$ & 0.05 & 0.012 & 0.017 & 0.003 \\
\hline GSH-Px (U/mL) & 200.73 & 210.27 & 213.00 & 229.36 & 218.18 & 219.27 & 3.00 & 0.110 & 0.027 & 0.127 \\
\hline $\mathrm{T}-\mathrm{AOC}(\mathrm{U} / \mathrm{mL})$ & 12.95 & 13.78 & 12.89 & 13.25 & 13.99 & 14.27 & 0.25 & 0.510 & 0.152 & 0.510 \\
\hline $\mathrm{SOD}(\mathrm{U} / \mathrm{mL})$ & $161.01^{b}$ & $170.73^{\mathrm{a}, \mathrm{b}}$ & $173.16^{\mathrm{a}, \mathrm{b}}$ & $175.59^{\mathrm{a}}$ & $173.47^{\mathrm{a}, \mathrm{b}}$ & $170.43^{a, b}$ & 1.46 & 0.048 & 0.038 & 0.009 \\
\hline $\operatorname{MDA}(\mathrm{nmol} / \mathrm{mL})$ & $7.02^{\mathrm{a}}$ & $6.04^{a, b}$ & $5.64^{\mathrm{b}}$ & $5.42^{b}$ & $5.70^{\mathrm{b}}$ & $5.32^{\mathrm{b}}$ & 0.14 & 0.001 & $<0.001$ & 0.023 \\
\hline
\end{tabular}

${ }^{1} \mathrm{CAT}=$ catalase; GSH-Px = glutathione peroxidase; T-AOC = total antioxidant capacity; SOD = superoxide dismutase; MDA = malondialdehyde; ${ }^{2}$ The content of $\alpha$-tocopherol in the basal diet was $15.45 \mathrm{mg} / \mathrm{kg}$; ${ }^{\mathrm{a}, \mathrm{b}}$ Means with different superscripts within the same column differ significantly $(p<0.05)$.

The effect of dietary VE supplementation on the liver antioxidant capacity of goslings on day 28 is presented in Table 7 . The activity of CAT in the liver of goslings in the $36 \mathrm{mg} / \mathrm{kg}$ group was higher than that in the $0 \mathrm{mg} / \mathrm{kg}$ groups $(p<0.05)$. The activity of GSH-Px in the liver of goslings in all groups had no significant differences $(p>0.05)$. The liver T-AOC in groups 12, 24, 36, 48 and $60 \mathrm{mg} / \mathrm{kg}$ was higher than that in group $0 \mathrm{mg} / \mathrm{kg}(p<0.05)$. The activity of SOD in the liver of goslings in the $60 \mathrm{mg} / \mathrm{kg}$ group was higher than that in the 0 groups $(p<0.05)$. The liver MDA content of goslings in the 24, 3648 and $60 \mathrm{mg} / \mathrm{kg}$ groups was less than that of the $0 \mathrm{mg} / \mathrm{kg}$ group $(p<0.05)$. The VE supplementation for male Jiangnan white goslings from 1 to 28 days of age was $25.94 \mathrm{mg} / \mathrm{kg}$ of the diet for minimum content of MDA in liver (Table 4). 
Table 7. Effect of dietary vitamin E supplementation on the antioxidant capacity in the liver of male Jiangnan white goslings on day 28.

\begin{tabular}{|c|c|c|c|c|c|c|c|c|c|c|}
\hline \multirow{2}{*}{ Item $^{1}$} & \multicolumn{6}{|c|}{ Vitamin E Supplementation Level (mg/kg) } & \multirow{2}{*}{ SEM } & \multicolumn{3}{|c|}{$p$-Value } \\
\hline & $0^{2}$ & 12 & 24 & 36 & 48 & 60 & & Vitamin E & Linear & Quadratic \\
\hline CAT (U/mg prot) & $38.65^{b}$ & $42.67^{\mathrm{a}, \mathrm{b}}$ & $46.41^{\mathrm{a}, \mathrm{b}}$ & $52.60^{\mathrm{a}}$ & $48.01^{\mathrm{a}, \mathrm{b}}$ & $47.70^{\mathrm{a}, \mathrm{b}}$ & 1.21 & 0.009 & 0.003 & 0.020 \\
\hline GSH-Px (U/mg prot) & 18.05 & 20.06 & 20.01 & 20.59 & 21.61 & 20.79 & 0.50 & 0.481 & 0.082 & 0.394 \\
\hline $\mathrm{T}-\mathrm{AOC}(\mathrm{U} / \mathrm{mg}$ prot $)$ & $8.10^{\mathrm{b}}$ & $10.49^{\mathrm{a}}$ & $10.83^{\mathrm{a}}$ & $10.04^{\mathrm{a}}$ & $10.34^{\mathrm{a}}$ & $10.31^{\mathrm{a}}$ & 0.25 & 0.016 & 0.034 & 0.017 \\
\hline SOD (U/mg prot) & $134.92^{b}$ & $145.38^{a, b}$ & $154.87^{\mathrm{a}, \mathrm{b}}$ & $164.92^{a, b}$ & $164.17^{a, b}$ & $172.78^{a}$ & 3.61 & 0.013 & $<0.001$ & 0.461 \\
\hline MDA (nmol/mg prot) & $0.66^{\mathrm{a}}$ & $0.53^{a, b}$ & $0.49^{b}$ & $0.41^{\mathrm{b}}$ & $0.46^{\mathrm{b}}$ & $0.51^{\mathrm{b}}$ & 0.02 & $<0.001$ & 0.001 & $<0.001$ \\
\hline
\end{tabular}

${ }^{1} \mathrm{CAT}=$ catalase; GSH-Px $=$ glutathione peroxidase; $\mathrm{T}-\mathrm{AOC}=$ total antioxidant capacity SOD = superoxide dismutase; MDA = malondialdehyde; ${ }^{2}$ The content of $\alpha$-tocopherol in the basal diet was $15.45 \mathrm{mg} / \mathrm{kg}$; ${ }^{\mathrm{a}, \mathrm{b}}$ Means with different superscripts within the same column differ significantly $(p<0.05)$.

\section{Discussion}

\subsection{Serum and Liver $\alpha$-Tocopherol Content}

Fat-soluble vitamins can be absorbed into the poultry body with lipids and stored in body in the other forms. $\alpha$-Tocopherol binds to various lipoproteins in the Golgi apparatus of epithelial cells to form chyme and then enters the lymphatic circulation. High-density lipoprotein (HDL) synthesized by intestinal cells could also carry $\alpha$-tocopherol into the blood circulation $[18,19]$. $\alpha$-Tocopherol was shown to be absorbed into the blood and entered the liver via the hepatic portal vein. Moreover, the liver tissue was shown to be the main organ of $\alpha$-tocopherol deposition [20]. The liver plays an important role in the storage, regulation and metabolism of $\alpha$-tocopherol [21]. Dynamic balance and regulatory mechanisms exist for $\alpha$-tocopherol levels in the blood and liver. $\alpha$-Tocopherol transfer protein ( $\alpha$-TTP) can transfer $\alpha$-tocopherol from the liver to the blood, effectively retaining $\alpha$-tocopherol in the body and significantly increasing the content of $\alpha$-tocopherol in serum [22]. Zhang et al. [23] showed that increasing the content of dietary VE could significantly increase the content of $\alpha$-tocopherol in plasma and liver of broilers. Russell et al. [24] showed that the levels of $\alpha$-tocopherol in the serum and liver of ducks in the group supplemented with $400 \mathrm{mg} / \mathrm{kg} \alpha$-tocopherol acetate were significantly higher than those in the control group supplemented with $20 \mathrm{mg} / \mathrm{kg} \alpha$-tocopherol. Our results showed that with increasing dietary VE supplementation, the content of $\alpha$-tocopherol in the serum and liver increased linearly.

\subsection{Growth Performance}

Adding the appropriate amount of VE to the diet can improve production performance of poultry. VE could regulate body metabolism through signal transduction to improve production performance $[25,26]$. Siegel et al. [27] and Boa-Amponsem et al. [28] observed that dietary VE supplementation could significantly increase the BW of broilers. Rebole et al. [29] reported that the BW and feed conversion ratio of female chickens in the group supplemented with $200 \mathrm{mg} / \mathrm{kg} \alpha$-tocopherol acetate were significantly higher than those in the non-supplemental group. Xie et al. [7] showed that the ADG of Peking ducks in groups supplemented with $10 \mathrm{mg} / \mathrm{kg}, 20 \mathrm{mg} / \mathrm{kg}$ and $100 \mathrm{mg} / \mathrm{kg} \alpha$-tocopherol acetate was significantly higher than that in the group supplemented with $0 \mathrm{mg} / \mathrm{kg} \alpha$-tocopherol acetate, and there were no differences in the ADG among the groups with $10 \mathrm{mg} / \mathrm{kg}$, $20 \mathrm{mg} / \mathrm{kg}$ and $100 \mathrm{mg} / \mathrm{kg} \alpha$-tocopherol acetate supplementation. In our study, dietary VE supplementation could increase the BW, ADG and reduce the F/G of goslings. Our results were consistent with those of previous studies. Our results were consistent with those of previous studies. These results showed that VE supplementation did not promote growth performance when the amount of $\mathrm{VE}$ added to the feed met the growth requirements. Another study observed that high doses of VE could reduce the production performance of poultry. When the dietary VE supplementation levels were 0 and $250 \mathrm{mg} / \mathrm{kg}$, the F/G of broilers was higher than the dietary VE supplementation level of $125 \mathrm{mg} / \mathrm{kg}$ [30]. In this experiment, based on broken-line regression analysis, the optimal VE supplementation 
level for male Jiangnan white goslings from 1 to $28 \mathrm{~d}$ of age was $12.51 \mathrm{mg} / \mathrm{kg}$ for maximum ADG.

\subsection{Immunity}

VE plays an important role in poultry immunity. VE could regulate the levels of cytokines and immunoglobulin in serum to enhance the immune ability of animals [31]. Lin and Chang [32] observed that dietary supplementation with $20 \mathrm{mg} / \mathrm{kg}$ VE could significantly improve the immune response of chickens. Liu et al. [33] found that the content of $\operatorname{IgA}$ and $\operatorname{IgG}$ in laying hens in a group supplemented with $30 \mathrm{IU} / \mathrm{kg}$ VE was higher than that in a group supplemented with $0 \mathrm{IU} / \mathrm{kg} \mathrm{VE}$, but had no significant effects on the content of IL-6 in the serum. In our study, VE increased the content of IgA and IgG in serum of goslings on day 28 , which was consistent with previous studies. Another study showed that the content of IFN- $\gamma$ in the serum of laying hens in the group supplemented with $50 \mathrm{mg} / \mathrm{kg}$ RRR- $\alpha$-tocopherol succinate was significantly lower than that in the group supplemented with $10 \mathrm{mg} / \mathrm{kg}$ RRR- $\alpha$-tocopherol succinate [8]. In this experiment, we observed the same results. IFN- $\gamma$ is a pro-inflammatory factor. The content of IFN- $\gamma$ in serum was reduced which suggested that VE could improve the immune capacity and reduce the inflammatory response of goslings on day 28. Our research showed that VE could enhance the humoral immunity of goslings by increasing the content of serum immunoglobulin and reducing inflammation to maintain the health of goslings. Improving immunity is beneficial for keeping animals in a healthy state and promoting growth.

\subsection{Serum and Liver Antioxidant Capacity}

VE can improve the antioxidant capacity of poultry. When the body produces too many free radicals or endogenous antioxidant enzymes and exogenous antioxidants are reduced, the imbalance between the generation and elimination of free radicals causes oxidative stress [34]. As an exogenous nonenzymatic antioxidant, VE can react with excess free radicals in the body and prevent free radical chain reactions, which play an important role in preventing lipid peroxidation and improving the activity of antioxidant enzymes in animals $[35,36]$. Studies have reported that with increasing dietary VE supplementation levels, the activity of antioxidant enzymes in serum was significantly increased and the MDA content in serum was significantly decreased [37,38]. Asghar et al. [18] observed that thiobarbituric acid reactive substances (TBARS) in the liver and muscle decreased with increasing of VE supplementation. Goi et al. [39] reported that the MDA content in chicken muscle of test groups was significantly less than that in chicken muscle of the control group. The results of this experiment showed that dietary VE supplementation could significantly increase the activities of CAT and SOD in the serum and liver. The T-AOC was also significantly increased in the liver, and dietary VE supplementation significantly decreased the content of MDA in the serum and liver. The results were consistent with those of previous studies. In our study, the content of $\alpha$-tocopherol in the serum and liver of goslings was increased, and $\alpha$-tocopherol improved the activity of antioxidant enzymes. With increasing $\alpha$-tocopherol content and antioxidant enzyme activity, the lipid peroxidation level has been shown to decrease [40,41]. Reducing lipid peroxidation could reduce the damage to cells and ensure the normal metabolism of cells [42]. In this experiment, adding appropriate VE to the diet improved the antioxidant capacity of goslings, reduced lipid peroxidation damage to organs and tissues, and improved immunity and growth performance.

\section{Conclusions}

In summary, adding an appropriate amount of VE to the diet can improve the growth performance, immunity and antioxidant capacity of male Jiangnan white goslings from 1 to $28 \mathrm{~d}$ of age. In this experiment, according to broken-line regression, the dietary VE supplementation level for average daily gain was $12.51 \mathrm{mg} / \mathrm{kg}$, but higher supplementation level should be considered to improve immunity and antioxidant capacity. 
Author Contributions: Z.W. and H.Y. conceived, designed the experiments; Q.S. performed the experiments; J.Y. and J.L. analyzed the data; X.X. contributed to analysis tools; Q.S. wrote the paper. All authors have read and agreed to the published version of the manuscript.

Funding: This work was financially supported by China Agriculture Research System of MOF and MARA, and major new varieties of agricultural projects in Jiangsu Province (PZCZ201738).

Institutional Review Board Statement: The animal study protocol was approved by the Institutional Review Board (or Ethics Committee) of Yangzhou University (Yangzhou, China) (protocol code SYXK (Su) IACUC and 2012-0029 of approval).

Conflicts of Interest: All the authors involved in this work declare that they have no conflict of interest.

\section{References}

1. Jensen, C.; Lauridsen, C.; Bertelsen, G. Dietary vitamin E: Quality and storage stability of pork and poultry. Trends Food Sci. Technol. 1998, 9, 62-72. [CrossRef]

2. Brigeliusflohe, R.; Kelly, F.J.; Salonen, J.T.; Neuzil, J.; Zingg, J.M.; Azzi, A. The european perspective on vitamin E: Current knowledge and future research. Am. J. Clin. Nutr. 2002, 76, 703-716. [CrossRef]

3. Guo, Y.; Tang, Q.; Yuan, J.; Jiang, Z. Effects of supplementation with vitamin E on the performance and the tissue peroxidation of broiler chicks and the stability of thigh meat against oxidative deterioration. Anim. Feed Sci. Technol. 2001, 89, 165-173. [CrossRef]

4. Ray, P.D.; Huang, B.W.; Tsuji, Y. Reactive oxygen species (ROS) homeostasis and redox regulation in cellular signaling. Cell. Signal. 2012, 24, 981-990. [CrossRef]

5. Guo, Y.M.; Zhang, G.M.; Yuan, J.M.; Nie, W. Effects of source and level of magnesium and vitamin e on prevention of hepatic peroxidation and oxidative deterioration of broiler meat. Anim. Feed Sci. Technol. 2003, 107, 143-150. [CrossRef]

6. Chae, B.J.; Lohakare, J.D.; Choi, J.Y. Effects of incremental levels of $\alpha$-tocopherol acetate on performance, nutrient digestibility and meat quality of commercial broilers. Asian-Australas. J. Anim. Sci. 2006, 19, 203-208. [CrossRef]

7. Xie, M.; Wang, S.; Huang, W.; Hou, S.S. Effects of vitamin E on growth performance, tissue $\alpha$-tocopherol, and lipid peroxidation of starter White Pekin ducks. Poult. Sci. 2018, 97, 2139-2143. [CrossRef] [PubMed]

8. Zhang, X.H.; Zhong, X.; Zhou, Y.M.; Wang, G.Q.; Du, H.M.; Wang, T. Dietary RRR-a-tocopherol succinate attenuates lipopolysaccharide-induced inflammatory cytokines secretion in broiler chicks. Br. J. Nutr. 2010, 104, 1796-1805. [CrossRef] [PubMed]

9. Kaiser, M.G.; Block, S.S.; Ciraci, C.; Fang, W.; Sifri, M.; Lamont, S.J. Effects of dietary vitamin E type and level on lipopolysaccharide-induced cytokine mRNA expression in broiler chicks. Poult. Sci. 2012, 91, 1893-1898. [CrossRef]

10. Leshchinsky, T.V.; Klasing, K.C. Relationship between the level of dietary vitamin E and the immune response of broiler chickens. Poult. Sci. 2001, 80, 1590-1599. [CrossRef] [PubMed]

11. Boler, D.D.; Gabriel, S.R.; Yang, H.; Balsbaugh, R.; Mahan, D.C.; Brewer, M.S.; McKeith, F.K.; Killefer, J. Effect of different dietary levels of natural-source vitamin $\mathrm{E}$ in grow-finish pigs on pork quality and shelf life. Meat Sci. 2009, 83, 723-730. [CrossRef]

12. Igarashi, A.; Uzuka, M.; Nakajima, K. The effects of vitamin E deficiency on rat skin. Br. J. Dermatol. 2010, 121, 43-49. [CrossRef]

13. Nemati, Z.; Alirezalu, K.; Besharati, M.; Amirdahri, S.; Franco, D.; José, M.L. Improving the quality characteristics and shelf life of meat and growth performance in goose fed diets supplemented with Vitamin E. Foods 2020, 9, 798. [CrossRef]

14. Ukaszewicz, E.; Kowalczyk, A.; Jerysz, A. Effect of dietary selenium and vitamin E on chemical and fatty acid composition of goose meat and liver. Anim. Sci. Pap. Rep. 2016, 34, 181-194.

15. National Research Council (NRC). Nutrient Requirements of Poultry, 9th ed.; The National Academies Press: Washington, DC, USA, 1994.

16. Jensen, S.K.; Engberg, R.M.; Hedemann, M.S. All-ractocopherol acetate is a better vitamin E source than all-rac-tocopherol succinate for broilers. J. Nutr. 1999, 129, 1355-1360. [CrossRef]

17. Robbins, K.R.; Saxton, A.M.; Southern, L.L. Estimation of nutrient requirements using broken-line regression analysis1. J. Anim. Sci. 2006, 84, 155-165. [CrossRef] [PubMed]

18. Anwar, K.; Iqbal, J.; Hussain, M.M. Mechanisms involved in vitamin E transport by primary enterocytes and in vivo absorption. J. Lipid Res. 2007, 48, 2028-2038. [CrossRef] [PubMed]

19. Emmanuelle, R.; Doriane, T.; Myriam, M.; Alexis, K.; Jean-Franois, L.; Giovanna, C.; Patrick, B. ATP-binding cassette transporter A1 is significantly involved in the intestinal absorption of alpha- and gamma-tocopherol but not in that of retinyl palmitate in mice. Am. J. Clin. Nutr. 2009, 89, 177-184. [CrossRef]

20. Asghar, A.; Gray, J.I.; Miller, E.R.; Pao-Kwen, K.; Booren, A.M.; Buckley, D.J. Influence of supranutritional vitamin E supplementation in the feed on swine growth performance and deposition in different tissues. J. Sci. Food Agric. 2010, 57, 19-29. [CrossRef]

21. Traber, M.G. Vitamin E regulatory mechanisms. Annu. Rev. Nutr. 2007, 27, 347-362. [CrossRef]

22. Kono, N.; Arai, H. Intracellular transport of Fat-Soluble vitamins A and E. Traffic 2015, 16, 19-34. [CrossRef] 
23. Zhang, X.H.; Zhong, X.; Zhou, Y.M.; Du, H.M.; Wang, T. Effect of RRR- $\alpha$-tocopherol succinate on the growth and immunity in broilers. Poult. Sci. 2009, 88, 959-966. [CrossRef]

24. Russell, E.A.; Lynch, P.B.; O'Sullivan, K.; Kerry, J.P. Dietary supplementation of $\alpha$-tocopherol acetate on $\alpha$-tocopherol levels in duck tissues and its influence on meat storage stability. Int. J. Food Sci. Technol. 2010, 3, 331-340. [CrossRef]

25. Zingg, J.M. Modulation of signal transduction by vitamin E. Mol. Aspects Med. 2007, 28, 481-506. [CrossRef]

26. Moazzami, A.A.; Frank, S.; Gombert, A.; Sus, N.; Bayram, B.; Rimbach, G.; Frank, J. Non-targeted 1h-nmr-metabolomics suggest the induction of master regulators of energy metabolism in the liver of vitamin E-deficient rats. Food Funct. 2015, 6, 1090-1097. [CrossRef]

27. Siegel, P.B.; Blair, M.; Gross, W.B.; Meldrum, B.; Larsen, C.; Boa-Amponsem, K.; Emmerson, D.A. Poult performance as influenced by age of dam, genetic line, and dietary vitamin E. Poult. Sci. 2006, 85, 939-942. [CrossRef] [PubMed]

28. Boa-Amponsem, K.; Picard, M.; Blair, M.E.; Meldrum, B.; Siegel, P.B. Memory antibody responses of broiler and leghorn chickens as influenced by dietary vitamin $\mathrm{E}$ and route of sheep red blood cell administration. Poult. Sci. 2006, 85, 173-177. [CrossRef]

29. Rebole, A.; Rodriguez, M.L.; Ortiz, L.T.; Alzueta, C.; Centeno, C.; Viveros, A.; Brenes, A.; Arija, I. Effect of dietary high-oleic acid sunflower seed, palm, oil and vitamin E supplementation on broiler performance, fatty acid composition and oxidation susceptibility of meat. Br. Poult. Sci. 2006, 47, 581-591. [CrossRef] [PubMed]

30. Habibian, M.; Ghazi, S.; Moeini, M.M.; Abdolmohammadi, A. Effects of dietary selenium and vitamin E on immune response and biological blood parameters of broilers reared under thermoneutral or heat stress conditions. Int. J. Biometeorol. $2014,58,741-752$. [CrossRef] [PubMed]

31. Dalia, A.M.; Loh, T.C.; Sazili, A.Q.; Jahromi, M.F.; Samsudin, A.A. Effects of vitamin E, inorganic selenium, bacterial organic selenium, and their combinations on immunity response in broiler chickens. BMC Vet. Res. 2018, 14, 249. [CrossRef]

32. Lin, Y.F.; Chang, S.J. Effect of dietary vitamin $\mathrm{E}$ on growth performance and immune response of breeder chickens. Asian-Australas. J. Anim. Sci. 2006, 19, 884-891. [CrossRef]

33. Liu, Y.J.; Zhao, L.H.; Mosenthin, R.; Zhang, J.Y.; Ji, C.; Ma, Q.G. Protective effect of vitamin E on laying performance, antioxidant capacity, and immunity in laying hens challenged with salmonella enteritidis. Poult. Sci. 2019, 98, 5847-5854. [CrossRef]

34. Lushchak, V.I. Free radicals, reactive oxygen species, oxidative stress and its classification. Chem-Biol. Interact. 2014, 224, 164-175. [CrossRef] [PubMed]

35. Gebicki, J.M. Oxidative stress, free radicals and protein peroxides. Arch. Biochem. Biophys. 2016, 595, 33-39. [CrossRef]

36. Poprac, P.; Jomova, K.; Simunkova, M.; Kollar, V.; Rhodes, C.J.; Valko, M. Targeting free radicals in oxidative stress-related human diseases. Trends Pharmacol. Sci. 2017, 38, 592-607. [CrossRef]

37. Li, Y.J.; Li, L.Y.; Li, J.L.; Zhang, L.; Zhou, G.H. Effects of dietary supplementation with ferulic acid or vitamin E individually or in combination on meat quality and antioxidant capacity of finishing pigs. Asian-Australas. J. Anim. Sci. 2015, 28, 374-381. [CrossRef]

38. Niu, Z.Y.; Min, Y.N.; Liu, F.Z. Dietary vitamin E improves meat quality and antioxidant capacity in broilers by upregulating the expression of antioxidant enzyme genes. J. Appl. Anim. Res. 2017, 46, 397-401. [CrossRef]

39. Goi, I.; Brenes, A.; Centeno, C.; Viveros, A.; Saura-Calixto, F.; Rebolé, A.; Arija, I.; Estevez, R. Effect of dietary grape pomace and vitamin E on growth performance, nutrient digestibility, and susceptibility to meat lipid oxidation in chickens. Poult. Sci. 2007, 86, 508-516. [CrossRef]

40. Espinosa-Diez, C.; Miguel, V.; Mennerich, D.; Kietzmann, T.; Sánchez-Pérez, P.; Cadenas, S.; Lamas, S. Antioxidant responses and cellular adjustments to oxidative stress. Redox. Biol. 2015, 6, 183-197. [CrossRef] [PubMed]

41. Pisoschi, A.M.; Pop, A. The role of antioxidants in the chemistry of oxidative stress: A review. Eur. J. Med. Chem. 2015, 46, 55-74. [CrossRef] [PubMed]

42. Sargis, R.M.; Subbaiah, P.V. Protection of membrane cholesterol by sphingomyelin against free radical-mediated oxidation. Free Radic. Biol. Med. 2006, 40, 2092-2102. [CrossRef] [PubMed] 